\title{
Effect of spirulina on the levels of zinc, vitamin E and linoleic acid in the palm skin extracts of people with prolonged exposure to arsenic
}

\author{
Mir Misbahuddin and Munira Afrin
}

Division of Arsenic Research, Department of Pharmacology, Faculty of Basic Medical Science and Paraclinical Science, Bangabnadhu Sheikh Mujib Medical University, Shahbag, Dhaka, Bangladesh.

\begin{tabular}{l} 
Article Info \\
\hline Received: $\quad$ 16 January 2013 \\
Accepted: 18 January 2013 \\
Available Online: $\quad$ F February 2013 \\
DOI: 10.3329/bjp.v8i1.13694 \\
\\
\\
Cite this article: \\
Misbahuddin M, Afrin M. Effect of \\
spirulina on the levels of zinc, vitamin \\
E and linoleic acid in the palm skin \\
extracts of people with prolonged \\
exposure to arsenic. Bangladesh J \\
Pharmacol. 2013; 8: 84-91.
\end{tabular}

\begin{abstract}
Spirulina, a dietary supplement, improves the symptoms of arsenical palmer keratosis. To understand its mechanism of action, palm skin extracts of moderate palmer arsenical keratosis $(n=10)$, arsenic exposed controls $(n=10)$ and healthy volunteers $(n=10)$ were collected before and after treatment with spirulina powder $10 \mathrm{~g} /$ day orally for 12 weeks. The mean $\pm \mathrm{SD}$ amount of zinc in the palm skin of healthy volunteers was $13.1 \pm 5.7 \mathrm{ng} / \mathrm{cm}^{2}$, which was not changed significantly in patients $\left(11.3 \pm 5.3 \mathrm{ng} / \mathrm{cm}^{2}\right)$. The amount of vitamin $\mathrm{E}$ in healthy volunteers was $6.0 \pm 0.3 \mathrm{ng} / \mathrm{cm}^{2}$ which was severely reduced in patients $\left(3.5 \pm 0.6 \mathrm{ng} / \mathrm{cm}^{2}\right)$. The amount of linoleic acid was lowered in patient $\left(26.7 \pm 17.1 \mathrm{ng} / \mathrm{cm}^{2}\right)$ which was statistically significant in comparison to healthy volunteers $(p=0.029)$. After supplementation of spirulina, zinc level in the palm skin of arsenic exposed controls was increased but it was not statistically significant $(p=0.068)$. The vitamin $E$ and linoleic acid levels were not changed significantly in the skin of palm. In conclusion, arsenical keratosis showed significantly low levels of vitamin E and linoleic acid without any significant change in zinc level. After supplementation of spirulina, low levels of these three compounds were not returned towards the normal levels.
\end{abstract}

\section{Introduction}

Thousands of people in Bangladesh, at present, are suffering from arsenical keratosis. Keratosis occurs in palms and soles. The involvement of palm and sole is always bilateral, that is, either both palms or soles or both palms and soles (Misbahuddin et al., 2011). The presence of keratosis in palm is a social problem, particularly in young unmarried girl.

Arsenical keratosis can be treated by either topical administration of drug or oral administration of dietary supplement or both. Topical administration of salicylic acid (Islam et al., 2007) or propylene glycol (Dina and Misbahuddin, 2010) improves the symptoms by soothing effect. Oral administration of beta-carotene, retinol (Hall, 1946), ascorbic acid, alpha-tocopherol, zinc (Kamaluddin and Misbahuddin, 2006), selenium (Nasir et al., 2002), folic acid, alpha-lipoic acid (Tabassum, 2006), spirulina (Fariduddin et al., 2001; Misbahuddin et al., 2006), spinach (Umar, 2007) and corn (Chowdhury et al., 2009) can reduce body arsenic load and improve clinical symptoms in skin manifestation in both experiment animal models and patients. These orally administered dietary supplementations are used either alone or in combination. However, longer duration (3-12 months) of treatment is required which ultimately affects patient's adherence. Stoppage of this supplementation recurs the symptoms of keratosis. 
Animal study shows that oral administration of either zinc or selenium increases the tissue accumulation of arsenic if co-administered with arsenic contaminated water (Misbahuddin and Kamaluddin, 2002). It is somewhat difficult to consume arsenic safe drinking water. Our foodstuff including staple food rice (Misbahuddin, 2003; Khan et al., 2007) is contaminated with arsenic. Among the orally administered supplements, spirulina requires shorter duration of treatment ( 3 months). In addition, it is a superfood containing high protein (up to $70 \%)$, vitamins, minerals, fatty acids and other nutrients (Karkos et al., 2011).

The skin of the palm and sole is thicker than the rest of the skin. Palmer skin has no sweat gland. Skin epidermis contains zinc (King et al., 2000), vitamin E (Thiele et al., 1999), and linoleic acid (Chu et al., 2003). Linoleic acid maintains physical barrier of skin by some buffer mechanism. Vitamin $\mathrm{E}$ and zinc are anti-oxidant that are required for methylation and detoxification of arsenic in the body, ultimately for the maintenance of health and for the development of optimal physical function (Saraymen et al., 2004). There is depletion of vitamin $\mathrm{E}$ on exposure to ultraviolet radiation (Thiele et al., 1998). Vitamin $\mathrm{E}$ has been found to inhibit cholesterol in patients with atherosclerosis (Stephens et al., 1996). Skin surface lipids are decreased in the uninvolved skin of the back of hands in patients with atopic dermatitis (Rajka, 1974). The role of zinc, vitamin $\mathrm{E}$ and linoleic acid in the pathogenesis of arsenical keratosis is not clear.

This study was designed to determine the levels of zinc, vitamin $\mathrm{E}$ and linoleic acid in the palmer skin of arsenical keratosis before and after supplementation of spirulina.

\section{Materials and Methods}

This study was carried out at Matlab Upazilla, Chandpur District (56 km away from Dhaka) from April to December, 2011. There were 13,000 tube wells present in this Upazilla of which about $65 \%$ are contaminated with high concentration of arsenic $(>50 \mu \mathrm{g} / \mathrm{L})$. A house of a patient was used as a temporary Arsenic Camp. At first 25 patients were selected randomly (computer generated serial number) from the record book of the Matlab Upazilla Health Complex. After inclusion and exclusion criteria, only 14 patients were finally diagnosed clinically as moderate palmer keratosis by a dermatologist. Considering the cost of the study, we finally selected 10 patients at random. Ten arsenic exposed controls were selected from the family members (1 or 2 from each family) of those patients. Ten healthy volunteers were selected from the same Upazilla.

\section{Inclusion criteria}

The age range of the participants were $20-40$ years. Both males and females were included. In case of arsenicosis patients, the inclusion criteria were: a) moderate palmer keratosis, b) drank arsenic contaminated water $(>50$ $\mu \mathrm{g} / \mathrm{L})$ for at least 6 months, c) voluntarily agreed to participate in this study. The inclusion criteria for arsenic exposed controls were: a) drank arsenic contaminated water $(>50 \mu \mathrm{g} / \mathrm{L})$ for at least 6 months, b) no skin manifestation, c) voluntarily agreed to participate. In case of healthy volunteers, the inclusion criteria were: a) drank arsenic safe water $(<50 \mu \mathrm{g} / \mathrm{L}), \mathrm{b})$ no skin manifestation, and c) voluntarily agreed to participate in this study. Moderate keratosis means palpable and visible wart as keratosis ( $>2$ to $5 \mathrm{~mm}$ ), appearing mainly or exclusively in a symmetric distribution on palm and sole (Caussy, 2005).

\section{Exclusion criteria}

The exclusion criteria were as follows; a) age $<20$ and $>40$ years, b) pregnant and lactating mother, c) any systemic disease, inflammatory disease and infectious condition that affects skin (diabetes mellitus, rheumatoid arthritis, systemic lupus erythromatosis), and d) patient getting any treatment of arsenicosis during the study period or within the last three months.

\section{Spirulina powder}

Spirulina powder was collected from the Bangladesh Council for Scientific and Industrial Research (a government organization). $150 \mathrm{~g}$ of spirulina powder was given to each participant in a container supplied with a plastic cup size holding $10 \mathrm{~g}$ of spirulina powder. Spirulina was supplied to each participant at 2 weeks interval. Every participant was advised to take a cup of spirulina powder mixed with rice during launch for 12 weeks. Compliance of the patient was assured by checking the empty container, while refiling spirulina in the next visit as well as frequent in touch with the patient using mobile phone.

\section{Collection of samples}

Drinking water $(50 \mathrm{~mL})$ and urine $(50 \mathrm{~mL})$ were collected in plastic container from the participants before starting the study to confirm the diagnosis as patient, arsenic exposed control or healthy volunteer. One drop of nitric acid was added to each container as a preservative. Skin extractions were collected in a glass container $(10 \mathrm{~mL}$ size) from both the sites of the palm and dorsum of right hand of each participant (Figure 1A).

A mixture of two organic solvents chloroform:ethanol $(2: 1 \mathrm{v} / \mathrm{v})$ was prepared. A glass container containing 4 $\mathrm{mL}$ of solvents was delineated over selected sites of the skin surface (area: $3.14 \mathrm{~cm}^{2}$ ) for $5 \mathrm{~min}$ (Figure 1A), and was pressed tightly by manual pressure and then removed (Figure 1B). The extracted solution was then kept for analysis of zinc, vitamin $\mathrm{E}$ and linoleic acid levels. Skin extracts from the palm and dorsum of the 

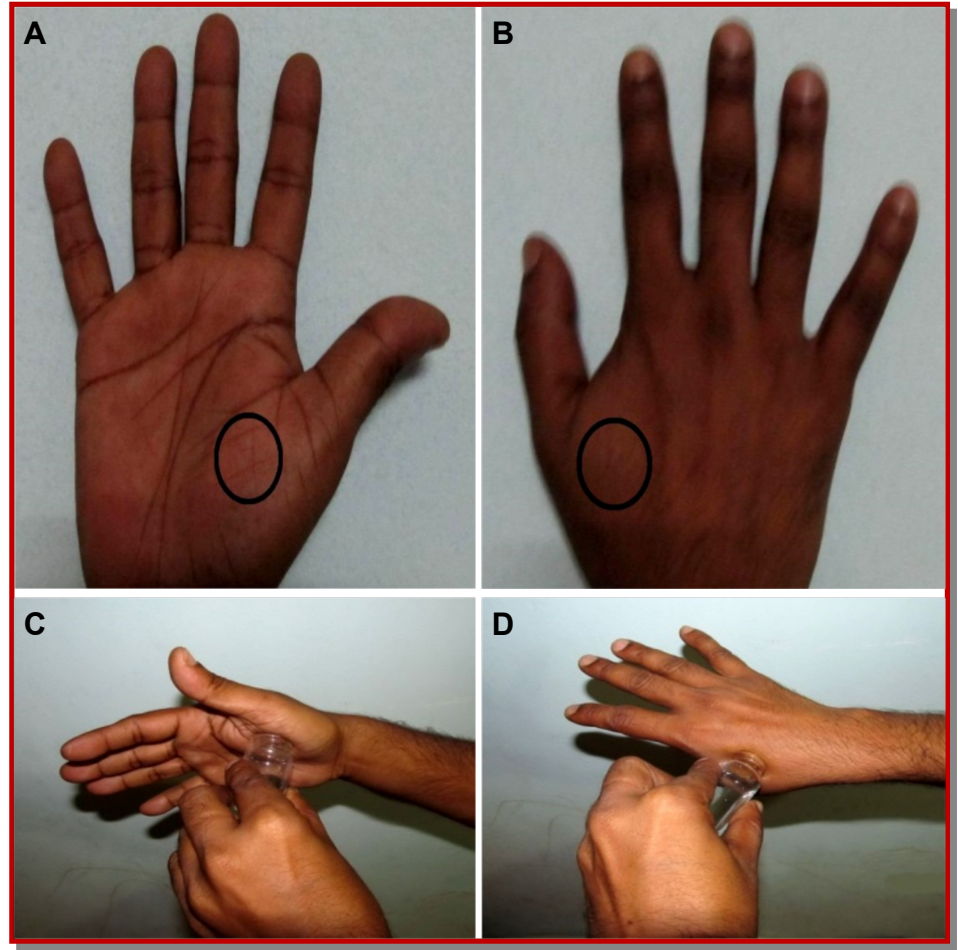

Figure 1: Sites from which the skin extract were collected. A) palmer side (area $\left.3.14 \mathrm{~cm}^{2}\right)$; B) dorsum side $\left(\operatorname{area} 3.14 \mathrm{~cm}^{2}\right)$. Procedure of extraction of zinc, vitamin E and linoleic acid from skin. C) before extraction (the solvent of chloroform and ethanol was not in touch of the skin); D) during extraction (the solvent of chloroform and ethanol was in touch of the skin) for 5 min

hand of each participant were collected twice (before and after intervention) at the field level. The samples (skin extract, water and urine) were carried out on the same day to the laboratory in a container maintaining about $-4^{\circ} \mathrm{C}$ temperature. Finally samples were kept at $20^{\circ} \mathrm{C}$ before estimation.

\section{Ethical consideration}

The ethical issue of this study was reviewed and approved by the Ethical Committee of Bangabandhu Sheikh Mujib Medical University.

\section{Data collection}

After taking the informed written consent, detailed history was taken by interview and clinical examinations were done focusing on arsenical palmer keratosis of the participants. All information of the study were recorded in data sheet.

\section{Estimation of arsenic (AOAC, 1975)}

Estimation of arsenic in water and urine samples were done by silver diethyldithiocarbamate (SDDC) method. In principle, inorganic arsenic was reduced to arsine $\left(\mathrm{AsH}_{3}\right)$ by zinc in strong acid solution in an arsine generator. The arsine was then passed through a scrubber containing cotton wool moistened with lead acetate into an absorber tube containing SDDC dissolved in chloroform. The arsine reacted with the silver salt, forming a soluble red color complex whose absorbance was read in a spectrophotometer (UV-VIS Spectrophotometer-1201, Shimadzu, Japan) at $525 \mathrm{~nm}$.

\section{Estimation of zinc (Fuwa et al., 1964)}

The amount of zinc in the skin extract was estimated by atomic absorption spectrometer. Zinc lamp (Buck Scientific, USA) was used with lamp current $2.0 \mathrm{~mA}$, slit setting $0.7 \mathrm{~nm}$, mode air/acetylene absorbance with wavelength of $213.9 \mathrm{~nm}$.

\section{Estimation of vitamin E (Baker and Frank, 1968)}

Vitamin E was estimated by reduction of ferric to ferrous ions which then formed a red complex with $a$, $a^{\prime}$-dipyridyl. Tocopherols and carotenes were first extracted into dichloromethane and the absorbance of blank was read at $460 \mathrm{~nm}$ to measure carotenes. A correction of carotenes was made after adding ferric chloride and absorbance was recorded at $520 \mathrm{~nm}$.

\section{Estimation of linoleic acid (Stein et al., 1992; Dann and Moore, 1933)}

The chromatographic system (ESA Biosciences, Inc., Chelmsford, USA) consisted of Model 210 VarianProstar solvent delivery module, ESA Model $520 \mathrm{UV} /$ Vis Detector, Rheodyne model 7725 injector with a 20 $\mu \mathrm{L}$ loop (Rheodyne Inc., Cotati, CA, USA) and Model DG4 degasser. Chromatographic separation was carried out on a Kromasil C18 reversed-phase column (4.6 mm $\times 250 \mathrm{~mm}$ ID, $5 \mu \mathrm{m}$ particle size (Eka Chemicals, Bohus, 


\section{Table I}

\section{Selected characteristics of the participants}

\begin{tabular}{|lrrr}
\hline Characteristics & \multicolumn{1}{c}{ Patients } & Arsenic exposed controls & Healthy volunteers \\
\hline Number & 10 & 10 & 10 \\
Age $($ Year) & $33.8 \pm 6.3$ & $33.3 \pm 5.7$ & $32.5 \pm 7.3$ \\
Male: Female & $4: 6$ & $6: 4$ & $7: 3$ \\
Amount of arsenic in tube well water $(\mu \mathrm{g} / \mathrm{L})$ & $646.5 \pm 148.0$ & $646.5 \pm 148.0$ & $35.1 \pm 4.1$ \\
Duration of arsenic exposure $($ Year) & $18.8 \pm 5.4$ & - & - \\
Duration of symptoms (Year) & $5.0 \pm 2.5$ & $77.1 \pm 27.8$ & Non-detectable level \\
Amount of arsenic in spot urine $(\mu \mathrm{g} / \mathrm{L})$ & $577.0 \pm 125.9$ &
\end{tabular}

Sweden). The mobile phase was acetonitrile-methanol-water 82:05:13 (v/v), which was filtered through a $0.45 \mu \mathrm{m}$ membrane filter (Millipore), and then degassed ultrasonically prior to use. The amount of linoleic acid in the product of trans-esterification of collected samples was analyzed by RP-HPLC with $\mathrm{UV}$ detector. The flow rate was $1.2 \mathrm{~mL} / \mathrm{min}$, the injection volume was $20 \mu \mathrm{L}$, the column temperature was maintained at $50^{\circ} \mathrm{C}$ and UV wavelength was set at $242 \mathrm{~nm}$. Linoleic acid was identified by comparing its retention time with that of the respective standard (F.A.M.E mix C14-C22) as well as cross-comparing with sunflower oil and soybean oil specimens as they contain highest concentration (\%) of linoleic acid. Quantification was carried out by the integration of area under the curve (AUC) with the help of the software EZchrom Elite (Scientific Software, Inc). Calculation of linoleic acid concentration was done manually from AUC of known standards.

\section{Statistical analysis}

One-way analysis of variance (ANOVA) was employed for comparisons among groups and paired Student's ' $t$ ' test was used for comparisons before and after treatment with spirulina. The data were expressed as mean \pm SD.

\section{Results}

The mean amounts $( \pm S D)$ of arsenic in the drinking water of patients, arsenic exposed controls and

Table II

Baseline zinc, vitamin $\mathrm{E}$ and linoleic acid levels at palm and dorsum skin of patients, arsenic exposed controls and healthy volunteers

\begin{tabular}{|c|c|c|c|c|c|c|c|}
\hline \multirow[t]{2}{*}{ Group } & & \multicolumn{2}{|c|}{ Zinc level } & \multicolumn{2}{|c|}{ Vitamin E } & \multicolumn{2}{|c|}{ Linoleic acid level } \\
\hline & & Mean \pm SD & $\mathrm{p}$ value & Mean \pm SD & $\mathrm{p}$ value & Mean \pm SD & $\mathrm{p}$ value \\
\hline \multicolumn{8}{|l|}{ Palm skin } \\
\hline Patients $(\mathrm{P})$ & & $11.3 \pm 5.3$ & 0.330 & $3.5 \pm 0.6$ & 0.000 & $26.7 \pm 17.1$ & 0.114 \\
\hline Arsenic exposed controls (A) & & $9.7 \pm 3.8$ & & $5.6 \pm 0.3$ & & $46.2 \pm 39.2$ & \\
\hline Healthy volunteers $(\mathrm{H})$ & & $13.1 \pm 5.7$ & & $6.0 \pm 0.3$ & & $59.5 \pm 40.5$ & \\
\hline & P vs A & 0.452 & & 0.000 & & 0.167 & \\
\hline & Pvs $\mathrm{H}$ & 0.458 & & 0.000 & & 0.030 & \\
\hline & A vs $\mathrm{H}$ & 0.131 & & 0.006 & & 0.464 & \\
\hline \multicolumn{8}{|l|}{ Dorsum skin } \\
\hline Patients $(\mathrm{P})$ & & $8.0 \pm 2.5$ & 0.069 & $3.4 \pm 0.6$ & 0.000 & $26.3 \pm 15.5$ & 0.018 \\
\hline Arsenic exposed controls (A) & & $9.9 \pm 3.5$ & & $3.7 \pm 0.6$ & & $34.6 \pm 22.8$ & \\
\hline Healthy volunteers $(\mathrm{H})$ & & $12.0 \pm 4.7$ & & $5.9 \pm 0.6$ & & $60.0 \pm 35.1$ & \\
\hline & P vs A & & 0.178 & & 0.372 & & 0.356 \\
\hline & $\mathrm{P}$ vs $\mathrm{H}$ & & 0.030 & & 0.000 & & 0.012 \\
\hline & A vs $\mathrm{H}$ & & 0.285 & & 0.000 & & 0.071 \\
\hline
\end{tabular}


Table III

\begin{tabular}{|c|c|c|c|c|c|c|c|c|c|}
\hline \multirow[t]{2}{*}{ Group } & \multirow[t]{2}{*}{$\mathrm{n}$} & \multicolumn{2}{|c|}{$\begin{array}{l}\text { Amount of zinc in palm skin } \\
\qquad\left(\mathrm{ng} / \mathrm{cm}^{2}\right)\end{array}$} & \multirow[t]{2}{*}{$\begin{array}{c}\text { Percent } \\
\text { increase/ } \\
\text { decrease }\end{array}$} & \multirow[t]{2}{*}{$\begin{array}{c}\mathrm{p} \\
\text { value }\end{array}$} & \multicolumn{2}{|c|}{$\begin{array}{l}\text { Amount of zinc in dor- } \\
\text { sum skin } \\
\left(\mathrm{ng} / \mathrm{cm}^{2}\right)\end{array}$} & \multirow[t]{2}{*}{$\begin{array}{l}\text { Percent } \\
\text { increase/ } \\
\text { decrease }\end{array}$} & \multirow[t]{2}{*}{$\begin{array}{c}\mathrm{p} \\
\text { value }\end{array}$} \\
\hline & & $\begin{array}{c}\text { Before } \\
\text { treatment }\end{array}$ & $\begin{array}{c}\text { After } \\
\text { treatment }\end{array}$ & & & $\begin{array}{l}\text { Before } \\
\text { treatment }\end{array}$ & $\begin{array}{c}\text { After } \\
\text { treatment }\end{array}$ & & \\
\hline Patients & 10 & $11.3 \pm 5.3$ & $10.6 \pm 5.7$ & $\downarrow 6.2 \%$ & 0.773 & $8.0 \pm 2.5$ & $9.3 \pm 4.7$ & $\uparrow 16.3 \%$ & 0.454 \\
\hline $\begin{array}{l}\text { Arsenic exposed } \\
\text { controls }\end{array}$ & 10 & $9.7 \pm 3.8$ & $14.0 \pm 5.7$ & $\uparrow 43.3 \%$ & 0.068 & $9.9 \pm 3.5$ & $9.5 \pm 5.4$ & $\downarrow 4.0 \%$ & 0.788 \\
\hline $\begin{array}{l}\text { Healthy volun- } \\
\text { teers }\end{array}$ & 10 & $13.1 \pm 5.7$ & $12.6 \pm 3.5$ & $\downarrow 3.8 \%$ & 0.808 & $12.0 \pm 4.7$ & $10.1 \pm 3.2$ & $\downarrow 15.8 \%$ & 0.312 \\
\hline
\end{tabular}

Table IV

Effect of spirulina on the amounts of vitamin $\mathrm{E}$ in the palm and dorsum skins of patients, arsenic exposed controls and healthy volunteers

\begin{tabular}{|c|c|c|c|c|c|c|c|c|c|}
\hline \multirow[t]{2}{*}{ Group } & \multirow[t]{2}{*}{$\mathrm{n}$} & \multicolumn{2}{|c|}{$\begin{array}{l}\text { Amount of vitamin E in } \\
\text { palm skin }\left(\mathrm{ng} / \mathrm{cm}^{2}\right)\end{array}$} & \multirow{2}{*}{$\begin{array}{c}\text { Percent } \\
\text { increase/ } \\
\text { decrease }\end{array}$} & \multirow[t]{2}{*}{$\begin{array}{c}\mathrm{p} \\
\text { value }\end{array}$} & \multicolumn{2}{|c|}{$\begin{array}{l}\text { Amount of vitamin } \mathrm{E} \text { in } \\
\text { dorsum skin }\left(\mathrm{ng} / \mathrm{cm}^{2}\right)\end{array}$} & \multirow{2}{*}{$\begin{array}{c}\text { Percent } \\
\text { increase/ } \\
\text { decrease }\end{array}$} & \multirow[t]{2}{*}{$\begin{array}{c}\mathrm{p} \\
\text { value }\end{array}$} \\
\hline & & $\begin{array}{c}\text { Before } \\
\text { treatment }\end{array}$ & $\begin{array}{c}\text { After } \\
\text { treatment }\end{array}$ & & & $\begin{array}{c}\text { Before } \\
\text { treatment }\end{array}$ & $\begin{array}{c}\text { After } \\
\text { treatment }\end{array}$ & & \\
\hline Patients & 10 & $3.5 \pm 0.6$ & $3.9 \pm 0.6$ & $\uparrow 11.4$ & 0.085 & $3.4 \pm 0.6$ & $3.6 \pm 0.6$ & $\uparrow 5.8$ & 0.491 \\
\hline $\begin{array}{l}\text { Arsenic exposed } \\
\text { controls }\end{array}$ & 10 & $5.6 \pm 0.3$ & $5.8 \pm 0.3$ & $\uparrow 3.5$ & 0.111 & $3.7 \pm 0.6$ & $4.1 \pm 0.3$ & $\uparrow 10.8$ & 0.055 \\
\hline $\begin{array}{l}\text { Healthy volun- } \\
\text { teers }\end{array}$ & 10 & $6.0 \pm 0.3$ & $6.0 \pm 0.0$ & $\rightarrow$ & 0.704 & $5.9 \pm 0.6$ & $6.1 \pm 0.6$ & $\uparrow 3.3$ & 0.472 \\
\hline
\end{tabular}

Table V

Effect of spirulina on the amounts of linoleic acid in the palm and dorsum skins of patients, arsenic exposed

\begin{tabular}{|c|c|c|c|c|c|c|c|c|c|}
\hline \multirow[t]{2}{*}{ Group } & \multirow[t]{2}{*}{$\mathrm{n}$} & \multicolumn{2}{|c|}{$\begin{array}{l}\text { Amount of linoleic acid in } \\
\text { palm skin }\left(\mathrm{ng} / \mathrm{cm}^{2}\right)\end{array}$} & \multirow[t]{2}{*}{$\begin{array}{l}\text { Percent } \\
\text { increase/ } \\
\text { decrease }\end{array}$} & \multirow[t]{2}{*}{$\begin{array}{c}\mathrm{p} \\
\text { value }\end{array}$} & \multicolumn{2}{|c|}{$\begin{array}{l}\text { Amount of linoleic acid } \\
\text { in dorsum skin (ng/ } \\
\left.\qquad \mathrm{cm}^{2}\right)\end{array}$} & \multirow[t]{2}{*}{$\begin{array}{c}\text { Percent } \\
\text { increase/ } \\
\text { decrease }\end{array}$} & \multirow[t]{2}{*}{$\begin{array}{c}\mathrm{p} \\
\text { value }\end{array}$} \\
\hline & & $\begin{array}{l}\text { Before } \\
\text { treatment }\end{array}$ & $\begin{array}{c}\text { After } \\
\text { treatment }\end{array}$ & & & $\begin{array}{c}\text { Before } \\
\text { treatment }\end{array}$ & $\begin{array}{c}\text { After } \\
\text { treatment }\end{array}$ & & \\
\hline Patients & 10 & $26.7 \pm 17.1$ & $31.9 \pm 15.5$ & $\uparrow 19.4$ & 0.482 & $26.3 \pm 15.5$ & $35.5 \pm 27.2$ & $\uparrow 35.0$ & 0.369 \\
\hline $\begin{array}{l}\text { Arsenic exposed } \\
\text { controls }\end{array}$ & 10 & $46.2 \pm 39.2$ & $61.3 \pm 35.7$ & $\uparrow 32.7$ & 0.378 & $34.6 \pm 22.8$ & $61.1 \pm 28.8$ & $\uparrow 76.6$ & 0.035 \\
\hline $\begin{array}{l}\text { Healthy volun- } \\
\text { teers }\end{array}$ & 10 & $59.5 \pm 40.5$ & $84.4 \pm 39.5$ & $\uparrow 41.8$ & 0.179 & $60.0 \pm 35.1$ & $83.6 \pm 30.7$ & $\uparrow 39.3$ & 0.124 \\
\hline
\end{tabular}

healthy volunteers were $646.5 \pm 148.0,646.5 \pm 148.0$, $35.1 \pm 4.1 \mu \mathrm{g} / \mathrm{L}$ respectively; Table I). Patients and arsenic exposed controls drunk water from the same tube well but the amounts of arsenic detected in spot urine were $577.0 \pm 125.9 \mu \mathrm{g} / \mathrm{L}$ in patients, $77.1 \pm 27.8$ $\mu \mathrm{g} / \mathrm{L}$ in arsenic exposed controls, non-detectable level in healthy volunteers. The mean duration of arsenic exposure was $18.8 \pm 5.4$ years in patients and $13.5 \pm 4.4$ years in arsenic exposed controls. The mean duration of appearance of symptoms in patients was $5.0 \pm 2.5$ years.

The palm skin of patients and arsenic exposed controls showed significant change in the amounts of vitamin $\mathrm{E}$ whereas the dorsum skin showed significant change in both vitamin E and linoleic acid levels (Table II).

There were no change in the amount of zinc, vitamin E and linoleic acid in the palm skins of patients, arsenic exposed controls and healthy volunteers following supplementation of spirulina for 12 weeks (Table III-V). Significant changes were observed in the vitamin $\mathrm{E}$ and linoleic acid levels of the dorsum skin of arsenic exposed controls.

\section{Discussion}

This study shows that amounts of vitamin $\mathrm{E}$ and 


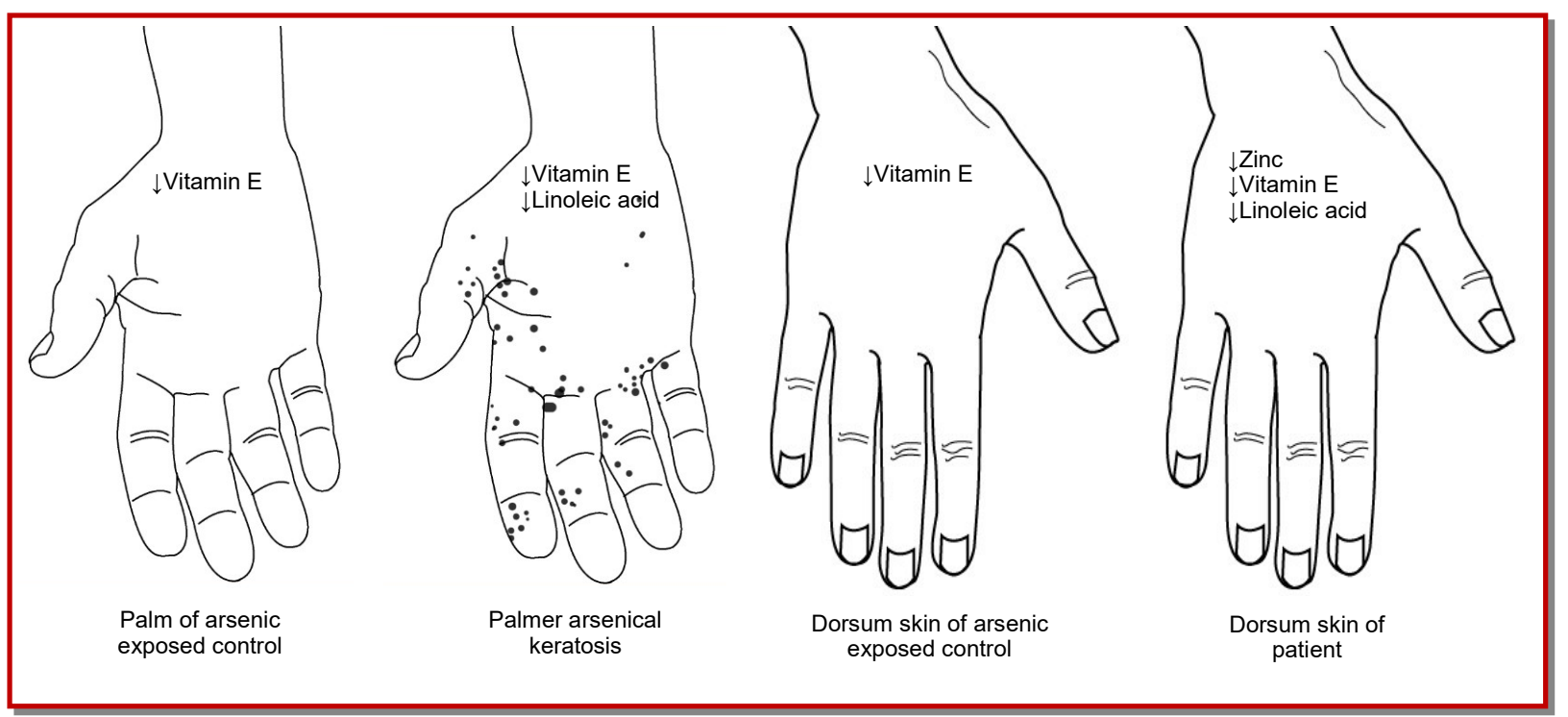

Figure 2: The levels of zinc, vitamin E and linoleic acid in the palmer and dorsum skins of patient and arsenic exposed control

linoleic acid in the palm skin of patients were low in comparison to health volunteers and arsenic exposed controls (Figure 2). However, the zinc level was not affected significantly. The amount of zinc, vitamin $\mathrm{E}$ and linoleic acid in the dorsum skin of patients were low in comparison to healthy volunteers and arsenic exposed controls. After supplementation of spirulina for 12 weeks, there were no significant increase in the level of zinc, vitamin $\mathrm{E}$ and linoleic acid level both in palm and dorsum skin. On arsenic exposure, there were no significant decrease in zinc and linoleic acid level in both palm and dorsum skin. But significant decrease in vitamin E levels in both the sites. After supplementation of spirulina, palmer skin shows no significant increase in zinc, vitamin $\mathrm{E}$ and linoleic acid. But dorsum skin shows significant increase in linoleic acid level.

When a person is consuming high concentration of arsenic chronically until the appearance of skin manifestation, then the skin of both palm and dorsum shows low amount of vitamin $\mathrm{E}$ without significant change in either zinc or linoleic acid levels. Arsenic produces oxidative stress (Wu et al., 2001) which ultimately affects vitamin E. Vitamin E is a lipid soluble anti-oxidant whereas zinc is a water soluble antioxidant. It is well-known that vitamin E protects longchain polyunsaturated fatty acids and thus maintain their concentrations for important signaling events (Traber and Atkinson, 2007). That is why, vitamin E level is decreased without affecting the fatty acid level like linoleic acid. In patient of palmer arsenical keratosis, the vitamin E level is further decreased and the normal level of linoleic acid is not maintained. Linoleic acid level is low. However, zinc level is not affected significantly. But it is quite interesting that the dorsum skin of patient cannot maintain the normal zinc level. That is, at the site of keratosis, the level of zinc is maintained to normal level.

Our previous study shows that the secretion of vitamin E from the site of skin having melanosis is higher in arsenic-exposed control and highest in patient (Yousuf et al., 2011). There is no data about the secretion of vitamin $\mathrm{E}$ and zinc from the palm of the patient and arsenic exposed control. Increased secretion of vitamin $\mathrm{E}$ from the palm skin, like the skin having melanosis, may be responsible for the low level of vitamin $\mathrm{E}$ in patient and arsenic exposed control. Similarly chronic intake of arsenic leads to several folds higher secretion of zinc from the site of skin having melanosis both in patients and in arsenic-exposed controls (Yousuf et al., 2011). One molecule of arsenic appears to be co-secreted with two molecules of zinc. It is quite natural to think that zinc level in the skin of palm must be low. In this study, low level of zinc is only observed in the dorsum skin of arsenic exposed controls. It remains unclear.

Spirulana is a superfood. It contains zinc, vitamin E and linoleic acid. So, it is quite natural to think that supplementation will increase the amount zinc, vitamin $E$ and linoleic acid in skin. Surprisingly, these substances are not increased even in healthy skin. Only linoleic acid level is increased in the dorsum skin of arsenic exposed controls. Supplementation with spirulina shows clinical improvement of keratosis (Misbahuddin et al., 2006). Our present study shows that there is no significant increase in the level of zinc, vitamin $\mathrm{E}$ and linoleic acid in the palmer as well as dorsum skin.

When a healthy person consumes chronically high concentration arsenic, then he/she develops at first mild keratosis, which subsequently deteriorated to form moderate and severe keratosis. If the pathological process continues, then malignancy develops. If we 
understand the pathological process of development of malignancy, then we can stop this skin manifestation following chronic consumption of arsenic. There are two peculiarities in the skin manifestations of Bangladeshi following chronic consumption of high concentration of arsenic. First, keratosis develops only at the palm or sole without affecting the skin of the rest of the body. Second, basal cell carcinoma is not common; instead a few cases of Bowen's disease are reported. In addition, all the members of a family consuming high concentration of arsenic but one or two may develop skin manifestations. We do not have the explanation of these two observations. Our diets have some unidentified components that may protect us from the consequences of consuming high concentration of arsenic.

Patients and arsenic exposed controls drunk water from same tube well but the amounts of arsenic detected in spot urine were several fold higher in patients than in arsenic exposed controls. The risk for skin lesions in relation to the arsenic exposure estimates based on urinary arsenic was elevated more than 3-fold (Ahsan et al., 2000). Our sample size is small. Further studies are required before drawing any conclusion.

\section{Conclusion}

Chronic arsenic exposure leads to low level of vitamin E in the skin of palm. In case of palmer keratosis, there is increased utilization of vitamin $\mathrm{E}$ followed by low amount of linoleic acid. Zinc level may have a role in the development of palmer keratosis. Supplementation with spirulina improves keratosis without significant increase in the level of vitamin $\mathrm{E}$ and linoleic acid at the palm skin.

\section{References}

Ahsan H, Perrin M, Rahman A, Parvez F, Stute M, Zheng Y, Milton AH, Brandt-Rauf P, van Geen A, Graziano J. Associations between drinking water and urinary arsenic levels and skin lesions in Bangladesh. JOEM. 2000; 42: 1195201.

AOAC (Association of Official Analytical Chemists 25. 006). $12^{\text {th }}$ ed. 1975. p 428.

Baker H, Frank O. Determination in serum tocopherol. In: Practical clinical biochemistry. Gowenlock AH (ed.). 6th ed. London, Heinemann Medical Books, 1968, p 902.

Caussy D (ed). A field guide for detection, management and surveillance of arsenicosis cases. New Delhi, WHO, Regional Office for South-East Asia, 2005.

Chowdhury NJA, Mir Misbahuddin M, Rahman MS. Corn extracts lower tissue arsenic level in rat. Bangladesh Med Res Counc Bull. 2009; 35: 21-25.
Chu DH, Haake AR, Holbrook $\mathrm{K}$, et al. The structure and development of the skin. In: Freedberg IM, Eisen AZ, Wolff $\mathrm{K}$, et al., (eds). Fitzpatrick's dermatology in general medicine. 6th ed. New York: McGraw-Hill, 2003; 58-88.

Dann WJ, Moore T. The absorption spectra of the mixed fatty acids from cod-liver oil. Nutritional Laboratory, University of Cambridge and Medical Research Council, 1933; 1166-69.

Dina AN, Misbahuddin M. Randomized double-blind trial to evaluate the effectiveness of topical administration of propylene glycol in arsenical palmer keratosis. Bangladesh J Pharmacol. 2010; 5: 98-102.

Fariduddin AKM, Misbahuddin M, Manun MIR, Nahar N Alcohol extract and residue of spirulina in the prevention of accumulation of arsenic in rats. Bangladesh J Physiol Pharmacol. 2001; 17: 15-17.

Fuwa K, Pulido P, Mckay R, Vallee BL. Determination of zinc in biological materials by atomic absorption spectrophotometry. Anal Chem. 1964; 36: 2407.

Hall AF. Arsenical keratosis disappearing with vitamin A therapy. Arch Derm Syph. 1946; 53: 154.

Islam AZMM, Misbahuddin M, Sikdar S, Biswas AK, Islam Z, Hadiuzzaman, Khandker S, Mahmud IA, Ahmad SA. Randomized controlled trial to evaluate the effectiveness of topical use of salicylic acid for treatment of keratosis in arsenicosis patients. In: Misbahuddin M (ed.), Applied research on arsenic in Bangladesh, Dhaka. World Health Organization (Bangladesh), Director General of Health Services, Govt. of Bangladesh, 2007, pp 92-100.

Kamaluddin M, Misbahuddin M. Zinc supplement reduces tissue arsenic concentration in rats. Bang Med Res Counc Bull. 2006; 32: 87-91.

Karkos PD, Leong SC, Karkos CD, Sivaji N, Assimakopoulos DA. Spirulina in Clinical Practice: Evidence-Based Human Applications. Evidence-Based Complement Alternat Med. 2011.

Khan MAR, Misbahuddin MS, Khandker S, Ifthaker-AlMahmud. Arsenic estimation in foodstuffs of arsenic exposed areas in Bangladesh. In: Applied research on arsenic in Bangladesh. Misbahuddin M (ed). World Health Organization, Dhaka, 2007, pp 31-42.

King JC, Shames DM, Woodhouse LR. Zinc homeostasis in humans. J Nutr. 2000; 130: 1360-66.

Misbahuddin M, Islam AZ, Khandker S, Ifthaker- AlMahmud, Islam N, Anjumanara. Efficacy of spirulina extract plus zinc in patients of chronic arsenicosis poisoning: A randomized placebo-controlled study. Clin Toxicol (Phila). 2006; 44: 135-141.

Misbahuddin M, Kamaluddin M. Simultaneous administration of zinc and arsenic enhances accumulation in tissues. BMJ. (rapid response) 14 November 2002.

Misbahuddin M, Khandker S, Jakariya M. Arsenic contamination of drinking water and foodstuffs. In: Drinking water contaminants in Bangladesh: Focuses on arsenic, fluoride, pesticides, manganese and cyanobacteria. Misbahuddin M, Khandker S (eds). Lambert Academic Publishing, Germany, 2011, pp 12-57. 
Misbahuddin M. Consumption of arsenic through cooked rice. Lancet 2003; 361: 435-36.

Nasir M, Misbahuddin M, Ali SMK. Selenium intervention in reducing arsenic levels in different tissues. In: Bangladesh Environment 2002, Proceedings of the 2nd International Conference on Bangladesh Environment. Ahmed MF, Tanveer SA, Badruzzaman ABM (eds). ICBEN-2002, Dhaka, Bangladesh, 2002, pp 343-52.

Rajka G. Surface lipid estimation on the back of the hands in atopic dermatitis. Arch Derm Forsch. 1974; 251: 43-48.

Saraymen R, Kilic E, Suleyman Y. Sweat copper zinc, iron, magnesium, and chromium levels in national wrestler. Inonu Universitesi Tip Fakultesi Dergisi. 2004; 11: 7-10.

Stein J, Kulemeier J, Lembcke B, Caspary WF. Simple and rapid method for determination of short-chain fatty acids in biological materials by high-performance liquid chromatography with ultraviolet detection. J Chromatogr. 1992; 576: 53.

Stephens NG, Parsons A, Schofield PM. Randomized controlled trial of vitamin $\mathrm{E}$ in patients with coronary disease: Cambridge Heart Anti-oxidant Study (CHAOS). Lancet 1996; 347: 781-86.

Tabassum NE. Effect of alpha-lipoic acid on the removal of arsenic from arsenic-loaded isolated liver tissues of rat. Bangladesh J Pharmacol. 2006; 1: 27-32.

Thiele JJ, Traber MG, Packer L. Depletion of human stratum corneum vitamin E: An early and sensitive in vivo marker of UV induced photo-oxidation. J Invest Dermatol. 1998; 110: 756-61.

Thiele JJ, Weber SU, Packer L. Sebaceous gland secretion is a major physiologic route of vitamin E delivery to skin. J Invest Dermatol. 1999; 113: 1006-10.

Traber MG, Atkinson J. Vitamin E, anti-oxidant and nothing more. Free Radical Biol Med. 2007; 43: 4-15.

Umar BU. Effect of hexane extract of spinach in the removal of arsenic from rat. Bangladesh J Pharmacol. 2007; 2: 27-34.

Wu MM, Chiou HY, Wang TW, Hsueh YM, Wang IH, Chen CJ, Lee TC. Association of blood arsenic levels with increased reactive oxidants and decreased anti-oxidant capacity in a human population of northeastern Taiwan. Environ Health Perspect. 2001; 109: 1011-17.

Yousuf AKM, Misbahuddin M, Rahman MS. Secretion of arsenic, cholesterol, vitamin E, and zinc from the site of arsenical melanosis and leucomelanosis in skin. Clin Toxicol. 2011; 49: 374-78.

\footnotetext{
Author Info

I Mir Misbahuddin (Principal contact)

e-mail: misbah@bdjpharmacol.com
} 